\title{
Research Article \\ Effects of Stress and MDMA on Hippocampal Gene Expression
}

\author{
Georg F. Weber, ${ }^{1}$ Bethann N. Johnson, ${ }^{2}$ Bryan K. Yamamoto, ${ }^{2}$ and Gary A. Gudelsky \\ ${ }^{1}$ James Winkle College of Pharmacy, University of Cincinnati, 3225 Eden Avenue, Cincinnati, OH 45267, USA \\ ${ }^{2}$ Department of Neurosciences, University of Toledo School of Medicine, Toledo, OH 43606, USA \\ Correspondence should be addressed to Gary A. Gudelsky; gary.gudelsky@uc.edu
}

Received 18 April 2013; Revised 18 September 2013; Accepted 10 October 2013; Published 9 January 2014

Academic Editor: Anton M. Jetten

Copyright (C) 2014 Georg F. Weber et al. This is an open access article distributed under the Creative Commons Attribution License, which permits unrestricted use, distribution, and reproduction in any medium, provided the original work is properly cited.

\begin{abstract}
MDMA (3,4-methylenedioxymethamphetamine) is a substituted amphetamine and popular drug of abuse. Its mood-enhancing short-term effects may prompt its consumption under stress. Clinical studies indicate that MDMA treatment may mitigate the symptoms of stress disorders such as posttraumatic stress syndrome (PTSD). On the other hand, repeated administration of MDMA results in persistent deficits in markers of serotonergic (5-HT) nerve terminals that have been viewed as indicative of 5-HT neurotoxicity. Exposure to chronic stress has been shown to augment MDMA-induced 5-HT neurotoxicity. Here, we examine the transcriptional responses in the hippocampus to MDMA treatment of control rats and rats exposed to chronic stress. MDMA altered the expression of genes that regulate unfolded protein binding, protein folding, calmodulin-dependent protein kinase activity, and neuropeptide signaling. In stressed rats, the gene expression profile in response to MDMA was altered to affect sensory processing and responses to tissue damage in nerve sheaths. Subsequent treatment with MDMA also markedly altered the genetic responses to stress such that the stress-induced downregulation of genes related to the circadian rhythm was reversed. The data support the view that MDMA-induced transcriptional responses accompany the persistent effects of this drug on neuronal structure/function. In addition, MDMA treatment alters the stress-induced transcriptional signature.
\end{abstract}

\section{Introduction}

3,4-Methylenedioxymethamphetamine (MDMA) is a ringsubstituted amphetamine analog. The primary effect of this drug is to alter perception, cognition, or mood. People who take it recreationally generally experience a feeling of elation [1]. Its short-term euphoria-inducing properties have made MDMA (ecstasy) a popular drug of abuse. These mood altering effects may also prompt MDMA intake by individuals who desire to overcome stressful experiences. In particular, MDMA treatment is under study to mitigate the clinical symptoms of PTSD [2]. However, it is not known whether or how the effects of MDMA may be altered in the context of chronic stress. It is conceivable that the pathophysiologic changes induced by stress could alter the efficacy or increase the toxicity of MDMA.

The hippocampus is a brain area that may be particularly susceptible to the effects of both MDMA and chronic stress. Chronic unpredictable stress suppresses neurogenesis within the hippocampus [3] and reduces dendritic complexity and spine density in this brain region $[4,5]$. Chronic stress also increases the vulnerability of hippocampal neurons to damage produced by neurotoxins and drugs [ 6 , 7]. The repeated administration of MDMA produces welldocumented, persistent deficits in biochemical markers of 5-HT axon terminals in multiple brain regions, including the hippocampus, in rodents and humans [8-11]. These findings have been viewed as evidence of MDMA-induced distal axotomy of 5-HT neurons [12]. Moreover, exposure to chronic unpredictable stress potentiates MDMA-induced 5HT neurotoxicity in the hippocampus [13].

Beyond the persistent effects of MDMA on 5-HT axon terminals, there is evidence that MDMA produces neuronal degeneration within multiple brain regions, including the hippocampus [14-17]. Although the identity of the targeted neuronal populations has not been determined, Anneken et al. [18] and Perrine et al. [19] have reported that MDMA 
reduces biochemical markers of hippocampal GABAergic neurons.

The hippocampus is known to be critical for learning and memory function [20]. Deficits in spatial learning and memory [21-24] and impairments in developing a conditioned place preference to sex [25] have been reported in rats treated with MDMA. In human abusers of MDMA, the most consistent finding is that of impairments in short-term memory, particularly verbal recall $[26,27]$, as well as deficits in tasks that assess executive functioning $[28,29]$.

The purpose of the present study was to investigate the interaction between chronic stress and MDMA treatment within the hippocampus at the molecular level, as evaluated from transcriptional responses quantified by microarray analysis.

\section{Materials and Methods}

2.1. Animals and Stress Exposure. Adult, male rats (250$300 \mathrm{~g}$ ) of the Sprague-Dawley strain (Harlan Laboratories, Indianapolis, IN) were used in this study. Animals had free access to food and water in a temperature- and humiditycontrolled room. All procedures were performed in adherence to the NIH guidelines and were approved by the institutional animal care and use committee.

Two groups of rats were exposed to chronic, unpredictable stress that consisted of various types, times, and durations of stressors. This regimen has been described previously [30] and consisted of the following: day 1: 10:00 a.m. 50min exposure to cold $\left(4^{\circ} \mathrm{C}\right)$ and 1:00 p.m. 60 min of restraint; day 2: 11:00 a.m. 60 min of cage agitation and 6:00 p.m. lights on overnight; day 3: 10:00 a.m. $3 \mathrm{hr}$ of lights off and 3:00 p.m. 3 min of swim stress; day 4: 11:00 a.m. 50 min of restraint and 5:00 p.m. food and water deprivation overnight; day 5: 12:00 p.m. 15 min cold room isolation and 12:30 p.m. isolation housing overnight; day 6: 10:00 a.m. 4 min of swim stress and 6:00 p.m. lights on overnight; day 7: 9:00 a.m. 2 hr of lights off and 6:00 p.m. food and water deprivation overnight; day 8: 10:00 a.m. $30 \mathrm{~min}$ of restraint and 3:00 p.m. $40 \mathrm{~min}$ of cage agitation; day 9: 11:00 a.m. 3 min swim stress and 6:00 p.m. lights on overnight; day 10: 10:00 a.m. 3 hr of lights off and 1:00 p.m. 20 min of cage agitation. Two groups of nonstressed rats were transported daily to the area of stressors but were not exposed to the stressors. After completion of each stressor, the rats were returned to the housing area.

2.2. Drug Treatment. Control and stress-exposed rats were injected with racemic 3,4-methylenedioxymethamphetamine (MDMA) (generously provided by the National Institute on Drug Abuse) or vehicle $(0.15 \mathrm{~N} \mathrm{NaCl}) 24 \mathrm{hr}$ following exposure to the last stressor. The rats received MDMA $(10 \mathrm{mg} / \mathrm{kg}$, ip) or vehicle at $2 \mathrm{hr}$ intervals for a total of 4 injections. The rats were euthanized for removal of the hippocampus $24 \mathrm{hr}$ following the first injection of MDMA or vehicle.

2.3. RNA Extraction and Hybridization. RNA was extracted from the hippocampi with $1.5 \mathrm{~mL}$ TriReagent according to the instructions by the manufacturer. The RNA samples were quantified by UV absorbance (260 and $280 \mathrm{~nm}$ ) and their integrity was confirmed by Agilent Bioanalyzer 2100 . Intact total RNA amounts of at least $50 \mathrm{ng}$ were amplified using the NuGen Applause WT-Amp Plus ST system (http://www.nugeninc.com/nugen/index.cfm/products/apl/ applause-rna-amplification-systems/). The samples were then biotinylated with the Ambion Biotin-Enhanced Message Amp II kit. The GeneChip Rat Gene 1.0 ST Array was hybridized with $2.5 \mu \mathrm{g}$ of fragmented biotinylated aRNA. The hybridization, staining, and washing were carried out using the Affymetrix GeneChip Hybridization Wash and Stain Kit following the manufacturer's protocols. Briefly, the arrays were hybridized for $16 \mathrm{hr}$ at $45^{\circ} \mathrm{C}$, followed by protocol FS450_0007 for staining and washing the GeneChips in the Affymetrix Fluidics Station 450. The GeneChips were scanned with Affymetrix GeneChip Scanner 30007 G using GCOS and software and preset settings. The Rat Gene 1.0 ST chip provides comprehensive coverage of the transcribed rat genome by analyzing over 27,000 protein coding transcripts, over 24,000 Entrez genes, and alternatively spliced transcript variants with probes designed to maximize coverage of exons. For each treatment group, there were 4-5 hybridizations.

2.4. Microarray Analysis. The data were analyzed to identify differentially expressed genes between the following conditions: (1) no stress saline versus stress saline, (2) no stress MDMA versus stress MDMA, (3) no stress saline versus no stress MDMA, and (4) stress saline versus stress MDMA. Four and five biological replicate arrays for Saline and MDMA samples, respectively, were performed.

Once the arrays had been scanned and the data files were generated, the results were analyzed by the UC Laboratory for Statistical Genomics and Systems Biology. Analysis was performed using statistical software $\mathrm{R}$ and the limma package of Bioconductor [31]. Data preprocessing, including background correction, normalization, and expression set summaries, was performed using RMA. Array quality was assessed using arrayQualityMetrics package of Bioconductor [32]. Estimated fold change for each comparison was calculated using ANOVA, and resulting $t$-statistics from each comparison were modified using an intensity-based empirical Bayes method (IBMT) [33]. Genes with $P$ value $<$ 0.05 , absolute fold change $>1.2$, and average intensity $>100$ fluorescent units were considered significantly differentially expressed. These cutoffs are consistent with similar studies in the literature [34-37]. Significant genes were further analyzed by Fisher's exact tests to identify overrepresented gene ontology categories and KEGG pathways. For these categories and pathways, a false discovery rate (FDR) below 0.05 and an odds ratio (log OR) outside the interval 0.67 to 1.5 were considered significant. To eliminate GO categories that are too broad to be informative, we focused on categories of fewer than 100 genes.

2.5. PCR Array and Real-Time RT-PCR. The microarray results for untreated and MDMA-treated rats were validated with the rat heat shock protein and chaperone PCR array 


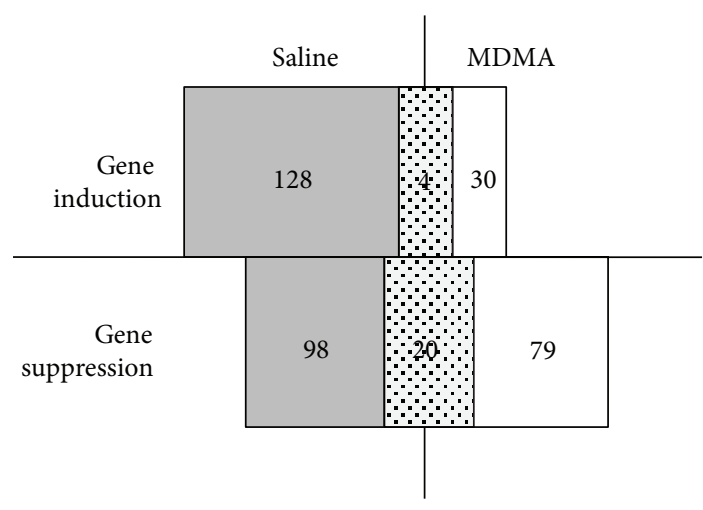

(a) Stress

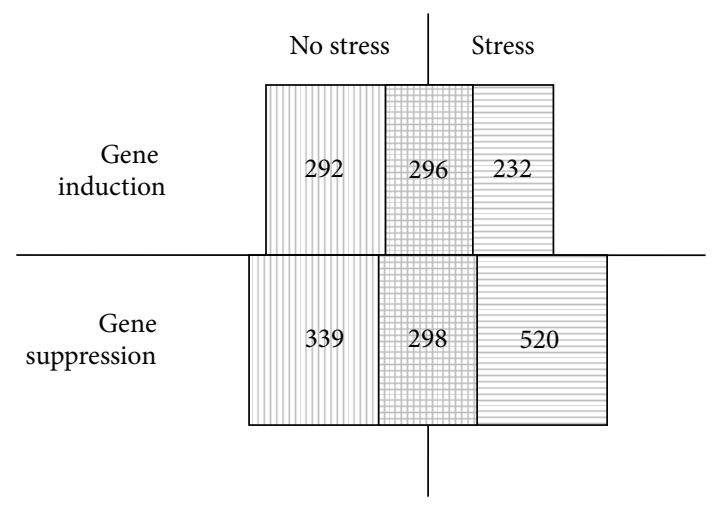

(b) MDMA

Figure 1: Gene expression changes following exposure to stress and MDMA. (a) Relative number of genes induced or suppressed by stress in the hippocampus of rats subsequently treated with saline or MDMA. Boxes outlined above the horizontal line indicate genes induced by stress and boxes outlined below the horizontal line indicate the number of genes suppressed by stress. Boxes outlined to the left and right of the vertical line indicated the number of genes up- or downregulated by saline or MDMA treatment, respectively. The shaded boxes in the middle of the diagram indicate the number of genes induced or suppressed by stress that were identical in saline and MDMA-treated animals and are considered MDMA-resistant. (b) Relative number of genes induced or suppressed by MDMA in the rat hippocampus of rats previously exposed to no stress or chronic unpredictable stress.

(SA Biosciences), which profiles the expression of 84 Heat Shock Protein genes that regulate protein folding. The array contains a set of optimized real-time PCR primer assays on a 96-well plate for pathway focused genes as well as appropriate RNA quality controls. It performs gene expression analysis with real-time PCR sensitivity and the multigene profiling capability of a microarray. The assay was run and evaluated at the SA Biosciences PCR Array Service.

For Per2, we measured the gene expression levels by real-time RT-PCR, using primers $5^{\prime}$-CTTCTGGTCTGGACTGCACA- $3^{\prime}$ (forward) and $5^{\prime}$-TGAGTCTGAGGTGGCAGATG- $3^{\prime}$ (reverse), $1.5 \mathrm{mM}$ magnesium, and $55^{\circ} \mathrm{C}$ annealing temperature for 40 cycles. Actin served as a loading control, and a reference cDNA validated each run.

\section{Results}

Exposure to chronic, unpredictable stress led to an overall moderate genetic response that comprised increases and decreases in gene expression levels. The consecutive administration of MDMA dramatically altered the profile of stressresponsive genes as follows.

(i) 118 genes were suppressed by stress alone. Most of these (i.e., 98) were distinct from the 99 genes suppressed by stress with ensuing exposure to MDMA (Figure 1(a)). Remarkably, there were 20 genes suppressed by stress in a fashion that was resistant to the consecutive exposure to MDMA (Table 1).

(ii) 132 genes were upregulated by stress alone. Most (i.e., 128) of these genes differed from the only 34 genes upregulated after stress with ensuing administration to MDMA (see Figure 1(a)). The significance of the four genes (hypothetical protein LOC689399, hypothetical protein LOC680454, and hypothetical protein LOC686031, similar to 60S ribosomal protein
L7a) induced by stress in a MDMA-resistant manner is unclear as all of them encode hypothetical or yet uncharacterized proteins.

(iii) Exposure to chronic stress resulted in altered gene expression in the KEGG pathway rno04710 (circadian rhythm). Four of twelve genes in this group were suppressed by stress, leading to a Fisher FDR of 3.23 $\times$ $10^{-02}$ and a $\log$ odds ratio of 2.95 . However, the stress-induced alteration in gene expression in the circadian rhythm pathway was not evident in stressed rats treated subsequently with MDMA (Table 2). For one of the affected genes, Per2, the stressdependent downregulation and MDMA-mediated reversal thereof was confirmed by real-time RT-PCR (not shown).

Exposure to MDMA led to the altered expression of 1225 genes in the hippocampus, with 588 genes being upregulated and 637 genes being suppressed (Figure 1(b)). Four gene ontology categories were affected (Table 3), comprising unfolded protein binding, protein folding, calmodulindependent protein kinase activity, and neuropeptide signaling pathway. The impact on protein folding seems to be of particular importance in the genetic response to MDMA as evidenced by the differential regulation of a large number of heat shock protein genes, for example, Hsp40, Hspd1, Hspa8, and Hsp90ab1 (Table 4(a)). The MDMA effect on heat shock proteins was validated by real-time RT-PCR array on samples from unstressed MDMA-treated versus unstressed untreated rats, which confirmed the MDMA-induced upregulation of several heat shock proteins and chaperones. In particular, Cct5, Dnajb1, Dnaja4, Dnajb11, Dnajb4, Hsp90ab1, Cct6a, SerpinH1, and Dnaja2 were increased under MDMA treatment in both microarray analysis and real-time RT-PCR (Table 4(b)). A moderate induction (1.2- to 1.4-fold) was seen 
TABLE 1: Stress suppressed genes that are resistant to consecutive MDMA exposure.

\begin{tabular}{|c|c|c|c|c|c|c|c|}
\hline \multirow{2}{*}{ Entrez ID } & \multirow{2}{*}{ Symbol } & \multirow{2}{*}{ Gene name } & \multirow[b]{2}{*}{ Average intensity } & \multicolumn{2}{|c|}{ No MDMA } & \multicolumn{2}{|c|}{ MDMA } \\
\hline & & & & -Fold change & $P$ value & -Fold change & $P$ value \\
\hline 361619 & MGC72973 & Beta-glo & 744.46 & -1.62 & 0.02 & -1.58 & 0.01 \\
\hline 287167 & LOC287167 & Globin, alpha & 512.31 & -1.61 & 0.02 & -1.29 & 0.04 \\
\hline 24440 & Hbb & Hemoglobin, beta & 1327.73 & -1.60 & 0.02 & -1.55 & 0.00 \\
\hline 499947 & Cbln 4 & Cerebellin 4 precursor & 103.48 & -1.51 & 0.04 & -1.78 & 0.00 \\
\hline 29139 & Dcn & Decorin & 203.33 & -1.45 & 0.04 & -1.43 & 0.00 \\
\hline 300850 & Gsta4 & Glutathione S-transferase, alpha 4 & 112.68 & -1.41 & 0.03 & -1.49 & 0.01 \\
\hline 362489 & Runxlt1 & $\begin{array}{l}\text { Runt-related transcription factor } 1 ; \\
\text { translocated to, } 1\end{array}$ & 152.25 & -1.36 & 0.04 & -1.22 & 0.00 \\
\hline 313729 & Errfil & ERBB receptor feedback inhibitor 1 & 725.49 & -1.35 & 0.00 & 1.21 & 0.00 \\
\hline 252917 & Nrld1 & $\begin{array}{l}\text { Nuclear receptor subfamily } 1 \text {, group D, } \\
\text { member } 1\end{array}$ & 347.48 & -1.34 & 0.00 & -1.45 & 0.00 \\
\hline 685671 & LOC685671 & Similar to myocyte enhancer factor $2 \mathrm{C}$ & 1233.46 & -1.31 & 0.02 & -1.34 & 0.00 \\
\hline 24330 & Egr1 & Early growth response 1 & 286.86 & -1.31 & 0.02 & -1.26 & 0.03 \\
\hline 289440 & Abhd7 & Abhydrolase domain containing 7 & 125.15 & -1.30 & 0.02 & -1.26 & 0.00 \\
\hline 308831 & Odz4 & $\begin{array}{l}\text { Odd Oz/ten-m homolog } 4 \\
\text { (Drosophila) }\end{array}$ & 162.69 & -1.26 & 0.01 & -1.25 & 0.00 \\
\hline 316351 & Npas2 & Neuronal PAS domain protein 2 & 255.91 & -1.25 & 0.01 & -1.24 & 0.00 \\
\hline 114858 & Shc3 & $\begin{array}{l}\text { Src homology } 2 \text { domain-containing } \\
\text { transforming protein } \mathrm{C} 3\end{array}$ & 301.74 & -1.24 & 0.00 & -1.26 & 0.00 \\
\hline 310358 & RGD1308448 & $\begin{array}{l}\text { Similar to RIKEN cDNA B130016O10 } \\
\text { gene }\end{array}$ & 169.03 & -1.23 & 0.03 & -1.22 & 0.00 \\
\hline 294250 & Bat2 & HLA-B associated transcript 2 & 266.79 & -1.22 & 0.01 & -1.22 & 0.00 \\
\hline 24309 & Dbp & $\begin{array}{l}\text { D site albumin promoter binding } \\
\text { protein }\end{array}$ & 961.48 & -1.21 & 0.00 & -1.28 & 0.00 \\
\hline 291356 & RGD1563437 & Similar to KIAA1217 & 116.04 & -1.21 & 0.04 & -1.22 & 0.00 \\
\hline 116470 & Stxla & Syntaxin 1A (brain) & 436.23 & -1.20 & 0.04 & -1.27 & 0.00 \\
\hline
\end{tabular}

Stress suppressed genes that are resistant to consecutive MDMA exposure. The average intensity of all genes shown is above threshold. All -fold changes and $P$ values are significantly differentially expressed as defined in Section 2.

TABLE 2: KEGG category rno04710 (circadian rhythm).

\begin{tabular}{|c|c|c|c|c|c|c|c|}
\hline \multirow{3}{*}{$\begin{array}{l}\text { Entrez } \\
\text { ID }\end{array}$} & \multirow{3}{*}{ Symbol } & \multirow{3}{*}{ Gene Name } & \multicolumn{5}{|c|}{ Stress versus no stress } \\
\hline & & & \multirow[b]{2}{*}{ Average intensity } & \multicolumn{2}{|c|}{ No MDMA } & \multicolumn{2}{|c|}{ MDMA } \\
\hline & & & & -Fold change & $P$ value & -Fold change & $P$ value \\
\hline 29657 & Arntl & Aryl hydrocarbon receptor nuclear translocator-like & 135.80 & -1.07 & 0.32 & -1.08 & 0.12 \\
\hline 63840 & Per2 & Period homolog 2 (Drosophila) & 108.53 & -1.21 & 0.01 & -1.12 & 0.14 \\
\hline 79431 & Bhlhb2 & Basic helix-loop-helix domain containing B2 & 638.68 & -1.03 & 0.73 & -1.07 & 0.15 \\
\hline 299691 & Cryl & Cryptochrome 1 (photolyase-like) & 116.72 & 1.12 & 0.15 & 1.12 & 0.03 \\
\hline 64462 & Csnk1d & Casein kinase 1 , delta & 271.06 & -1.05 & 0.37 & -1.03 & 0.38 \\
\hline 58822 & Csnkle & Casein kinase 1, epsilon & 382.89 & -1.02 & 0.74 & -1.09 & 0.02 \\
\hline 287422 & Per1 & Period homolog 1 (Drosophila) & 165.79 & -1.34 & 0.00 & 1.00 & 0.91 \\
\hline 170917 & Cry2 & Cryptochrome 2 (photolyase-like) & 540.10 & -1.09 & 0.10 & -1.13 & 0.01 \\
\hline 60447 & Clock & Circadian locomoter output cycles kaput & 244.29 & -1.14 & 0.02 & 1.01 & 0.84 \\
\hline 252917 & Nrld1 & Nuclear receptor $1 D 1$ & 347.48 & -1.34 & 0.00 & -1.45 & 0.00 \\
\hline 316351 & Npas2 & Neuronal PAS domain protein 2 & 255.91 & -1.25 & 0.01 & -1.24 & 0.00 \\
\hline 78962 & Per3 & Period homolog 3 (Drosophila) & 115.64 & -1.10 & 0.25 & -1.05 & 0.35 \\
\hline
\end{tabular}

The average intensity of all genes shown is above threshold. Fold changes above or below threshold and significant $P$ values are shown in bold. On this basis, the italicized genes are judged to be suppressed by stress. 
TABLE 3: Gene ontology analysis of MDMA-induced genes in the hippocampus.

\begin{tabular}{|c|c|c|c|c|c|c|}
\hline \multirow{3}{*}{$\begin{array}{l}\text { Category } \\
\text { type }\end{array}$} & \multirow{3}{*}{$\begin{array}{l}\text { Category } \\
\text { ID }\end{array}$} & \multirow{3}{*}{ Category description } & \multicolumn{4}{|c|}{ No stress } \\
\hline & & & \multicolumn{4}{|c|}{ No MDMA versus MDMA } \\
\hline & & & $\begin{array}{l}\text { Genes in } \\
\text { category }\end{array}$ & $\begin{array}{c}\text { All genes in } \\
\text { category }\end{array}$ & $\begin{array}{c}\text { Fisher } \\
\text { FDR }\end{array}$ & $\log \mathrm{OR}$ \\
\hline GO & GO:0051082 & Unfolded protein binding & 21.00 & 63.00 & 0.00 & 2.00 \\
\hline GO & GO:0006457 & Protein folding & 25.00 & 94.00 & 0.00 & 1.68 \\
\hline GO & GO:0004683 & $\begin{array}{l}\text { Calmodulin-dependent } \\
\text { protein kinase activity }\end{array}$ & 7.00 & 14.00 & 0.01 & 2.65 \\
\hline GO & GO:0007218 & $\begin{array}{c}\text { Neuropeptide signaling } \\
\text { pathway }\end{array}$ & 7.00 & 19.00 & 0.04 & 2.16 \\
\hline
\end{tabular}

All rats were unstressed. FDR: false discovery rate. log OR: logarithm of the odds ratio.

in the PCR array in Cct3, Tcpl, and Cct4 (not shown), which were comparably moderately increased in the microarray.

According to gene ontology analysis, the genetic response by unstressed rats to MDMA (described in the preceding paragraph) was different from the genetic response by stressed rats to MDMA, indicating that MDMA induces altered responses to tissue damage in nerve sheaths and altered sensory processing in stressed, but not unstressed individuals as follows.

(i) When compared to stressed rats not treated with MDMA, the administration of MDMA following stress downregulated the related categories wound healing (FDR $1.30 \times 10^{-5}, \log$ OR 1.626), tissue regeneration (FDR $1.76 \times 10^{-3}, \log$ OR 1.761 ), myeloid leukocyte activation (FDR $2.30 \times 10^{-2}, \log$ OR 2.03), and cytokine-cytokine receptor interaction (FDR $3.01 \times 10^{-2}, \log$ OR 1.638). Further, stress plus MDMA versus stress alone suppressed ensheathment of neurons (FDR $2.47 \times 10^{-3}, \log$ OR 1.595), axon ensheathment (FDR $2.47 \times 10^{-3}, \log$ OR 1.595), myelination (FDR $5.33 \times 10^{-3}, \log$ OR 1.556), and myelin sheath $\left(8.17 \times 10^{-3}, \log\right.$ OR 2.436). This suggests that tissue damage conferred by MDMA on the stressed hippocampus was exerted particularly to the axon sheaths. MDMA had no effect on these gene ontology categories when given to unstressed rats.

(ii) When compared to stressed rats treated with saline, administration of MDMA following stress upregulated the related categories rhodopsin-like receptor activity (FDR $1.54 \times 10^{-4}, \log$ OR 1.733), sensory perception of chemical stimulus (FDR $3.22 \times 10^{-3}, \log$ OR 2.537), neurotransmitter binding (FDR $8.49 \times 10^{-3}, \log$ OR 1.807), neurotransmitter receptor activity (FDR $8.49 \times 10^{-3}, \log$ OR 1.962), sensory perception of smell (FDR $1.89 \times 10^{-2}, \log$ OR 2.469), response to protein stimulus (FDR $2.11 \times 10^{-2}, \log$ OR 1.894 ), and detection of stimulus involved in sensory perception (FDR $3.59 \times 10^{-2}, \log$ OR 2.246). This implies sensory changes exerted by MDMA on the stressed, but not the unstressed hippocampus.

\section{Discussion}

The present study examined the effects of chronic stress and subsequent MDMA treatment on gene transcription in the rat hippocampus. The key findings are the following: (1) MDMA alone increases the expression of genes in several gene ontology categories, including protein folding and unfolded protein binding, (2) MDMA upregulates the genes for several heat shock proteins, (3) MDMA negatively affects the expression of genes related to axon sheaths and tissue remodeling in stressed rats, (4) chronic stress alters gene expression within the circadian rhythm pathway, and this effect is absent in rats treated subsequently with MDMA, and (5) the number of stress-responsive genes is lessened by MDMA treatment.

The genetic responses to repeated stress included over two hundred genes that were either up- or downregulated. The reduction in the number of these genes by consecutive MDMA administration implies the potential for a druginduced amelioration of the stress response. Among the genetic adaptations to stress, transcripts in the KEGG pathway for circadian rhythm were downregulated in response to chronic, unpredictable stress. One prominent clinical characteristic of stress disorder, particularly PTSD, in humans is abnormalities in the circadian rhythms of several physiological responses such as cortisol, blood pressure, and sleep [3840]. In the present study, the suppressive effect of stress on gene transcription within the KEGG pathway for circadian rhythm was not manifest in stressed rats treated subsequently with MDMA. There is evidence that MDMA may affect sleep cycles [41], implying that it could have the potential to reverse or reduce stress-induced sleep disturbance. MDMA has been shown to be beneficial in treating the symptoms of PTSD [2]. While it is not yet known whether this clinical response is related to a restoration of circadian rhythms, the anxiolytic drug prazosin can reduce stress-induced sleep disturbances [42], providing a rationale for non-antidepressant restoration of the circadian rhythm. In general, MDMA is under discussion for the treatment of anxiety disorders [43]. This drug significantly altered the pattern of stress-induced gene induction and suppression. It remains to be determined whether the ability of MDMA to alter the genetic response to stress is of significance in the clinical response of PTSD patients to MDMA. 
TABle 4: (a) Genome GO:0051082 (unfolded protein binding). (b) Real-time PCR array of chaperone and heat shock genes.

(a)

\begin{tabular}{|c|c|c|c|c|c|c|c|c|c|c|c|}
\hline \multirow{3}{*}{$\begin{array}{l}\text { Entrez } \\
\text { ID }\end{array}$} & \multirow{3}{*}{ Symbol } & \multirow{3}{*}{ Gene name } & \multirow{3}{*}{$\begin{array}{l}\text { Average } \\
\text { intensity }\end{array}$} & \multicolumn{4}{|c|}{ Stress versus no stress } & \multicolumn{4}{|c|}{ MDMA versus no MDMA } \\
\hline & & & & \multicolumn{2}{|c|}{ No MDMA } & \multicolumn{2}{|c|}{ MDMA } & \multicolumn{2}{|c|}{ No stress } & \multicolumn{2}{|c|}{ Stress } \\
\hline & & & & $\begin{array}{l}\text {-Fold } \\
\text { change }\end{array}$ & $P$ value & $\begin{array}{l}\text {-Fold } \\
\text { change }\end{array}$ & $P$ value & $\begin{array}{l}\text {-Fold } \\
\text { change }\end{array}$ & $P$ value & $\begin{array}{l}\text {-Fold } \\
\text { change }\end{array}$ & $P$ value \\
\hline 361384 & Dnajb1 & $\begin{array}{l}\text { DnaJ (Hsp40) homolog, } \\
\text { subfamily B, member } 1\end{array}$ & 363.16 & 1.02 & 0.81 & -1.09 & 0.50 & 2.18 & 0.00 & 1.96 & 0.00 \\
\hline 65028 & Dnajal & $\begin{array}{l}\text { DnaJ (Hsp40) homolog, } \\
\text { subfamily A, member } 1\end{array}$ & 1222.76 & 1.04 & 0.43 & 1.03 & 0.51 & 1.45 & 0.00 & 1.44 & 0.00 \\
\hline 295549 & Dnajb4 & $\begin{array}{l}\text { DnaJ (Hsp40) homolog, } \\
\text { subfamily B, member } 4\end{array}$ & 668.67 & 1.02 & 0.73 & 1.01 & 0.87 & 1.42 & 0.00 & 1.40 & 0.00 \\
\hline 300721 & Dnaja4 & $\begin{array}{l}\text { DnaJ (Hsp40) homolog, } \\
\text { subfamily A, member } 4\end{array}$ & 232.20 & 1.07 & 0.48 & -1.10 & 0.21 & 1.39 & 0.01 & 1.18 & 0.01 \\
\hline 288620 & Cct6a & chaperonin subunit $6 a$ (zeta) & 395.91 & 1.03 & 0.73 & -1.02 & 0.50 & 1.37 & 0.00 & 1.30 & 0.00 \\
\hline 360734 & Dnajbl1 & $\begin{array}{l}\text { DnaJ (Hsp40) homolog, } \\
\text { subfamily B, member } 11\end{array}$ & 472.49 & 1.01 & 0.93 & -1.02 & 0.75 & 1.36 & 0.00 & 1.33 & 0.00 \\
\hline 29345 & Serpinh1 & $\begin{array}{l}\text { Serine (or cysteine) peptidase } \\
\text { inhibitor, clade } \mathrm{H} \text {, member } 1\end{array}$ & 469.00 & -1.04 & 0.77 & -1.12 & 0.47 & 1.36 & 0.15 & 1.26 & 0.00 \\
\hline 295230 & Cct3 & $\begin{array}{l}\text { chaperonin subunit } 3 \\
\text { (gamma) }\end{array}$ & 686.33 & 1.03 & 0.62 & -1.06 & 0.26 & 1.35 & 0.00 & 1.24 & 0.00 \\
\hline 311456 & Mkks & $\begin{array}{l}\text { McKusick-Kaufman } \\
\text { syndrome protein }\end{array}$ & 320.40 & 1.06 & 0.33 & 1.02 & 0.81 & 1.35 & 0.00 & 1.30 & 0.00 \\
\hline 64202 & Calr & Calreticulin & 1882.72 & 1.03 & 0.63 & -1.05 & 0.29 & 1.32 & 0.00 & 1.22 & 0.00 \\
\hline 63868 & Hspd1 & $\begin{array}{l}\text { Heat shock protein } 1 \\
\text { (chaperonin) }\end{array}$ & 1509.64 & 1.01 & 0.83 & -1.00 & 0.98 & 1.28 & 0.01 & 1.26 & 0.00 \\
\hline 29374 & Cct 4 & Chaperonin subunit 4 (delta) & 662.36 & 1.03 & 0.63 & -1.04 & 0.45 & 1.28 & 0.00 & 1.20 & 0.00 \\
\hline 25719 & Scg5 & Secretogranin V & 2031.48 & 1.05 & 0.34 & -1.00 & 0.94 & 1.26 & 0.00 & 1.19 & 0.00 \\
\hline 362862 & Tral & Tumor rejection antigen gp96 & 2797.04 & 1.03 & 0.63 & 1.04 & 0.33 & 1.25 & 0.01 & 1.26 & 0.00 \\
\hline 24818 & Tcp1 & t-complex protein 1 & 474.45 & 1.02 & 0.80 & -1.01 & 0.81 & 1.24 & 0.00 & 1.20 & 0.01 \\
\hline 301252 & Hsp90ab1 & $\begin{array}{l}\text { Heat shock protein } 90 \mathrm{kDa} \\
\text { alpha (cytosolic), class B } \\
\text { member } 1\end{array}$ & 4755.12 & 1.01 & 0.72 & -1.03 & 0.35 & 1.24 & 0.00 & 1.18 & 0.00 \\
\hline 24468 & Hspa8 & Heat shock protein 8 & 3661.99 & 1.02 & 0.84 & 1.06 & 0.33 & 1.22 & 0.03 & 1.27 & 0.00 \\
\hline 294864 & Cct5 & $\begin{array}{l}\text { Chaperonin subunit } 5 \\
\text { (epsilon) }\end{array}$ & 1223.73 & 1.04 & 0.45 & 1.01 & 0.82 & 1.22 & 0.00 & 1.18 & 0.00 \\
\hline 368044 & Atp6vlg2 & $\begin{array}{l}\text { ATPase, } \mathrm{H}+\text { transporting, } \mathrm{V} 1 \\
\text { subunit } \mathrm{G} \text { isoform } 2\end{array}$ & 1494.80 & 1.02 & 0.72 & -1.03 & 0.38 & 1.22 & 0.00 & 1.15 & 0.00 \\
\hline 294236 & Gtf2h4 & $\begin{array}{l}\text { General transcription factor II } \\
\mathrm{H} \text {, polypeptide } 4\end{array}$ & 106.29 & 1.08 & 0.39 & -1.04 & 0.36 & 1.21 & 0.01 & 1.08 & 0.22 \\
\hline 84026 & Dnaja2 & $\begin{array}{l}\text { DnaJ (Hsp40) homolog, } \\
\text { subfamily A, member } 2\end{array}$ & 1040.62 & 1.05 & 0.47 & 1.06 & 0.06 & 1.21 & 0.00 & 1.23 & 0.00 \\
\hline 619393 & Dnajc12 & $\begin{array}{l}\text { DnaJ (Hsp40) homolog, } \\
\text { subfamily C, member } 12\end{array}$ & 367.66 & 1.06 & 0.29 & -1.01 & 0.72 & 1.21 & 0.00 & 1.12 & 0.03 \\
\hline 89811 & Vegfb & $\begin{array}{l}\text { Vascular endothelial growth } \\
\text { factor B }\end{array}$ & 330.14 & -1.03 & 0.66 & -1.04 & 0.33 & -1.22 & 0.01 & -1.23 & 0.00 \\
\hline 299313 & Uxt & $\begin{array}{l}\text { Ubiquitously expressed } \\
\text { transcript }\end{array}$ & 616.75 & -1.05 & 0.51 & 1.04 & 0.20 & -1.29 & 0.00 & -1.19 & 0.00 \\
\hline
\end{tabular}


(a) Continued.

\begin{tabular}{|c|c|c|c|c|c|c|c|c|c|c|c|}
\hline \multirow{3}{*}{$\begin{array}{l}\text { Entrez } \\
\text { ID }\end{array}$} & \multirow{3}{*}{ Symbol } & \multirow{3}{*}{ Gene name } & \multirow{3}{*}{$\begin{array}{l}\text { Average } \\
\text { intensity }\end{array}$} & \multicolumn{4}{|c|}{ Stress versus no stress } & \multicolumn{4}{|c|}{ MDMA versus no MDMA } \\
\hline & & & & \multicolumn{2}{|c|}{ No MDMA } & \multicolumn{2}{|c|}{ MDMA } & \multicolumn{2}{|c|}{ No stress } & \multicolumn{2}{|c|}{ Stress } \\
\hline & & & & $\begin{array}{l}\text {-Fold } \\
\text { change }\end{array}$ & $P$ value & $\begin{array}{l}\text {-Fold } \\
\text { change }\end{array}$ & $P$ value & $\begin{array}{l}\text {-Fold } \\
\text { change }\end{array}$ & $P$ value & $\begin{array}{l}\text {-Fold } \\
\text { change }\end{array}$ & $P$ value \\
\hline 29427 & Aif1 & $\begin{array}{l}\text { Allograft inflammatory factor } \\
1\end{array}$ & 172.49 & -1.07 & 0.47 & -1.25 & 0.00 & -1.39 & 0.00 & -1.62 & 0.00 \\
\hline
\end{tabular}

Individual members of the gene ontology category Unfolded Binding Protein are shown. The average intensity of all genes shown is above threshold. Fold changes and $P$ values beyond the cutoff for significance are in bold. For clarity, genes that do not reach significance in any category are not shown. Genes induced by MDMA are separated by a free line.

(b)

\begin{tabular}{lc}
\hline Gene symbol & Fold regulation \\
\hline Hspa5 & 2.6069 \\
Cct5 & 2.5859 \\
Dnajb1 & 2.3823 \\
Cryab & 2.3305 \\
Hspb1 & 2.2668 \\
Hspa2 & 2.215 \\
Bag3 & 2.0596 \\
Dnaja4 & 1.8908 \\
Cct7 & 1.8412 \\
Dnajb11 & 1.8159 \\
Hspa14 & 1.8117 \\
Dnajb4 & 1.7724 \\
Ldha & 1.7399 \\
Dnaja1 & 1.6982 \\
Hsph1 & 1.6806 \\
Dnajc7 & 1.6537 \\
Hsp90ab1 & 1.5955 \\
Cct6a & 1.5808 \\
Hsp90aal & 1.5609 \\
Cct2 & 1.5112 \\
Hsp90b1 & 1.5025 \\
Serpinh1 & 1.4973 \\
Dnaja2 & 1.4346 \\
Hspa41 & 1.4198 \\
\hline & \\
\hline
\end{tabular}

Real-time PCR validation of chaperone and heat shock gene upregulation by MDMA exposure ( 2 rats) versus unstressed untreated rats ( 3 rats). Fold change $\left(2^{-\Delta \Delta \mathrm{Ct}}\right)$ is the normalized gene expression $\left(2^{-\Delta \mathrm{Ct}}\right)$ in the test sample divided by the normalized gene expression $\left(2^{-\Delta \mathrm{Ct}}\right)$ in the control sample. Fold regulation represents fold change results in a biologically meaningful way. Fold change values greater than one indicate a negative or downregulation and the fold regulation is the negative inverse of the fold change. Shown are positive changes in fold regulation by MDMA of at least 1.4 over controls.

One component of the psychopharmacology of MDMA is that human abusers of the drug report enhanced sensory perceptions. In the present study, MDMA administration to chronically stressed rats exhibited an upregulation of related gene categories associated with sensory perception when compared to stressed rats not given MDMA. These findings suggest that MDMA may exert persistent effects on sensory perception that outlast the acute effects of the drug on neurotransmitter release.
Exposure to prior chronic stress impacted the genetic responses to MDMA. Notably, gene categories of tissue regeneration, axon ensheathment, myelin sheath, and cytokinecytokine receptor interaction were significantly downregulated following MDMA treatment to rats exposed to chronic stress when compared to unstressed rats given MDMA or to stressed rats not given MDMA. Hence, chronic stress appears to augment the deleterious effects of MDMA on the neuronal structure. Callahan et al. [44] have concluded 
that MDMA produces structural damage to axonal transport mechanisms in multiple brain regions. The susceptibility to that damage or the intensity of the damage may be enhanced consecutively to stressing experiences. Although the identity of neurons affected by the combination of stress and MDMA is unknown, it is of interest that chronic, unpredictable stress augments the persistent deficits in serotonergic neurons produced by MDMA [30].

The gene expression changes observed in this study are consistent with the existing literature. The MDMA-induced alterations in gene ontology categories are consistent with transcriptional events associated with drug-induced neuronal damage. Genes related to protein folding and unfolded protein binding were upregulated 24 hours following MDMA treatment. Gene transcripts for heat shock proteins were notably upregulated following MDMA administration. This finding is consistent with previous reports that MDMA increases heat shock protein mRNAs in the mouse striatum [16] and heat shock protein levels in several brain regions [45-47]. The effects of MDMA on heat shock protein gene expression are viewed as a response to cellular stress that may accompany MDMA-induced hyperthermia and/or oxidative stress.

Treatment with MDMA also increased gene expression in GO categories related to cell signaling (e.g., neuropeptide signaling pathway and calmodulin-dependent protein kinase activity). This finding is in accord with the reports of Thiriet et al. [48] and Salzmann et al. [16] in which MDMA was shown to increase transcription for several proteins belonging to signal transduction pathways. These changes can be viewed, most likely, as a consequence of 5-HT receptor activity subsequent to the MDMA-induced increase in extracellular 5-HT in the hippocampus [49].

The use of psychedelic drugs to treat emotional disorders has been controversial due to the intrinsic neurotoxicity of these agents [1]. The evaluation of such therapies largely depends, in the short term, on cognitive and psychological evaluations that may be particularly susceptible to placebo effects or interpretive differences. The supplementation of clinical studies with ex vivo molecular assessments may aid in providing mechanistic insights. The present investigation of hippocampal gene expression profiles has elucidated the potential of MDMA to ameliorate the genetic response to chronic unpredictable stress and to reverse stress-induced sleep disorders. However, it has also found evidence that the toxicity of MDMA on nerve sheaths may be increased in individuals previously exposed to stressful experiences.

\section{Conflict of Interests}

The authors declare that there is no conflict of interests regarding the publication of the paper.

\section{Acknowledgment}

This work was supported, in part, by USPHS DA047247.

\section{References}

[1] E. Check, "The ups and downs of ecstasy," Nature, vol. 429, no. 6988, pp. 126-128, 2004.

[2] M. C. Mithoefer, M. T. Wagner, A. T. Mithoefer et al., "Durability of improvement in post-traumatic stress disorder symptoms and absence of harmful effects or drug dependency after 3, 4methylenedioxymethamphetamine-assisted psychotherapy: a prospective long-term follow-up study," Journal of Psychopharmacology, vol. 27, pp. 28-39, 2013.

[3] A. J. Eisch and D. Petrik, "Depression and hippocampal neurogenesis: a road to remission?" Science, vol. 338, pp. 72-75, 2012.

[4] Q. Liu, J. Yu, Q.-L. Mao-Ying et al., "Repeated clomipramine treatment reversed the inhibition of cell proliferation in adult hippocampus induced by chronic unpredictable stress," Pharmacogenomics Journal, vol. 8, no. 6, pp. 375-383, 2008.

[5] B. S. McEwen, "The ever-changing brain: cellular and molecular mechanisms for the effects of stressful experiences," Developmental Neurobiology, vol. 72, pp. 878-890, 2012.

[6] R. M. Sapolsky, "A mechanism for glucocorticoid toxicity in the hippocampus: Increased neuronal vulnerability to metabolic insults," The Journal of Neuroscience, vol. 5, no. 5, pp. 1228-1232, 1985.

[7] B. Stein-Behrens, M. P. Mattson, I. Chang, M. Yeh, and R. Sapolsky, "Stress exacerbates neuron loss and cytoskeletal pathology in the hippocampus," The Journal of Neuroscience, vol. 14, no. 9, pp. 5373-5380, 1994.

[8] A. R. Green, A. O. Mechan, J. M. Elliott, E. O'Shea, and M. I. Colado, "The pharmacology and clinical pharmacology of 3,4-methylenedioxymethamphetamine (MDMA, "ecstasy")," Pharmacological Reviews, vol. 55, no. 3, pp. 463-508, 2003.

[9] G. A. Gudelsky and B. K. Yamamoto, "Neuropharmacology and neurotoxicity of 3,4-methylenedioxymethamphetamine," Methods in molecular medicine, vol. 79, pp. 55-73, 2003.

[10] S. J. Kish, J. Lerch, Y. Furukawa et al., "Decreased cerebral cortical serotonin transporter binding in ecstasy users: a positron emission tomography/[11C]DASB and structural brain imaging study," Brain, vol. 133, no. 6, pp. 1779-1797, 2010.

[11] U. D. McCann, V. Eligulashvili, and G. A. Ricaurte, “( $\pm( \pm, 4$ Methylenedioxymethamphetamine ("ecstasy")-induced serotonin neurotoxicity: clinical studies," Neuropsychobiology, vol. 42, no. 1, pp. 11-16, 2000.

[12] T. Xie, L. Tong, M. W. McLane et al., "Loss of serotonin transporter protein after MDMA and other ring-substituted amphetamines," Neuropsychopharmacology, vol. 31, no. 12, pp. 2639-2651, 2006.

[13] B. N. Johnson and B. K. Yamamoto, "Chronic unpredictable stress augments +3,4-methylenedioxymethamphetamineinduced monoamine depletions: the role of corticosterone," Neuroscience, vol. 159, no. 4, pp. 1233-1243, 2009.

[14] F. Kermanian, M. Mehdizadeh, M. Soleimani et al., "The role of adenosine receptor agonist and antagonist on hippocampal MDMA detrimental effects, a structural and behavioral study," Metabolic Brain Disease, vol. 27, pp. 459-469, 2012.

[15] I. Riezzo, D. Cerretani, C. Fiore et al., "Enzymaticnonenzymatic cellular antioxidant defense systems response and immunohistochemical detection of MDMA, VMAT2, HSP70, and apoptosis as biomarkers for MDMA (ecstasy) neurotoxicity," Journal of Neuroscience Research, vol. 88, no. 4, pp. 905-916, 2010. 
[16] J. Salzmann, C. Canestrelli, F. Noble, and C. Marie-Claire, "Analysis of transcriptional responses in the mouse dorsal striatum following acute 3,4-methylenedioxymethamphetamine (ecstasy): Identification of extracellular signal-regulated kinasecontrolled genes," Neuroscience, vol. 137, no. 2, pp. 473-482, 2006.

[17] M. W. Warren, S. F. Larner, F. H. Kobeissy et al., "Calpain and caspase proteolytic markers co-localize with rat cortical neurons after exposure to methamphetamine and MDMA," Acta Neuropathologica, vol. 114, no. 3, pp. 277-286, 2007.

[18] J. H. Anneken, J. I. Cunningham, S. A. Collins, B. K. Yamamoto, and G. A. Gudelsky, "MDMA increases glutamate release and reduces parvalbumin-positive GABAergic cells in the dorsal hippocampus of the rat: role of cyclooxygenase," Journal of NeuroImmune Pharmacology, vol. 8, pp. 58-65, 2013.

[19] S. A. Perrine, F. Ghoddoussi, M. S. Michaels, E. M. Hyde, D. M. Kuhn, and M. P. Galloway, "MDMA administration decreases serotonin but not N-acetylaspartate in the rat brain," NeuroToxicology, vol. 31, no. 6, pp. 654-661, 2010.

[20] R. P. Kesner, "A behavioral analysis of dentate gyrus function," Progress in Brain Research, vol. 163, pp. 567-576, 2007.

[21] J. A. Able, G. A. Gudelsky, C. V. Vorhees, and M. T. Williams, "3,4-methylenedioxymethamphetamine in adult rats produces deficits in path integration and spatial reference memory," Biological Psychiatry, vol. 59, no. 12, pp. 1219-1226, 2006.

[22] J. I. Cunningham, J. Raudensky, J. Tonkiss, and B. K. Yamamoto, "MDMA pretreatment leads to mild chronic unpredictable stress-induced impairments in spatial learning," Behavioral Neuroscience, vol. 123, no. 5, pp. 1076-1084, 2009.

[23] J. E. Sprague, A. S. Preston, M. Leifheit, and B. Woodside, "Hippocampal serotonergic damage induced by MDMA (ecstasy): effects on spatial learning," Physiology and Behavior, vol. 79, no. 2, pp. 281-287, 2003.

[24] C. V. Vorhees, T. M. Reed, M. R. Skelton, and M. T. Williams, "Exposure to 3,4-methylenedioxymethamphetamine (MDMA) on postnatal days 11-20 induces reference but not working memory deficits in the Morris water maze in rats: implications of prior learning," International Journal of Developmental Neuroscience, vol. 22, no. 5-6, pp. 247-259, 2004.

[25] M. M. W. Straiko, G. A. Gudelsky, and L. M. Coolen, “Treatment with a serotonin-depleting regimen of MDMA prevents conditioned place preference to sex in male rats," Behavioral Neuroscience, vol. 121, no. 3, pp. 586-593, 2007.

[26] K. I. Bolla, U. D. McCann, and G. A. Ricaurte, "Memory impairment in abstinent MDMA ("Ecstasy") users," Neurology, vol. 51, no. 6, pp. 1532-1537, 1998.

[27] M. J. Morgan, "Ecstasy (MDMA): a review of its possible persistent psychological effects," Psychopharmacology, vol. 152, no. 3, pp. 230-248, 2000.

[28] N. A. Von Geusau, P. Stalenhoef, M. Huizinga, J. Snel, and K. R. Ridderinkhof, "Impaired executive function in male MDMA (“ecstasy") users," Psychopharmacology, vol. 175, no. 3, pp. 331341, 2004.

[29] M. Wareing, J. E. Fisk, and P. N. Murphy, "Working memory deficits in current and previous users of MDMA ("ecstasy")," British Journal of Psychology, vol. 91, part 2, pp. 181-188, 2000.

[30] B. N. Johnson and B. K. Yamamoto, "Chronic stress enhances the corticosterone response and neurotoxicity to +3,4-methylenedioxymethamphetamine (MDMA): the role of ambient temperature," Journal of Pharmacology and Experimental Therapeutics, vol. 335, no. 1, pp. 180-189, 2010.
[31] G. K. Smyth, "Linear models and empirical bayes methods for assessing differential expression in microarray experiments," Statistical Applications in Genetics and Molecular Biology, vol. 3, no. 1, article 3, 2004.

[32] A. Kauffmann, R. Gentleman, and W. Huber, "arrayQualityMetrics-a bioconductor package for quality assessment of microarray data," Bioinformatics, vol. 25, no. 3, pp. 415-416, 2009.

[33] M. A. Sartor, C. R. Tomlinson, S. C. Wesselkamper, S. Sivaganesan, G. D. Leikauf, and M. Medvedovic, "Intensity-based hierarchical Bayes method improves testing for differentially expressed genes in microarray experiments," BMC Bioinformatics, vol. 7, article 538, 2006.

[34] K.-S. Kim and P.-L. Han, "Optimization of chronic stress paradigms using anxiety- and depression-like behavioral parameters," Journal of Neuroscience Research, vol. 83, no. 3, pp. 497-507, 2006.

[35] M. Orsetti, F. Di Brisco, P. L. Canonico, A. A. Genazzani, and P. Ghi, "Gene regulation in the frontal cortex of rats exposed to the chronic mild stress paradigm, an animal model of human depression," European Journal of Neuroscience, vol. 27, no. 8, pp. 2156-2164, 2008.

[36] I. Sillaber, M. Panhuysen, M. S. H. Henniger et al., "Profiling of behavioral changes and hippocampal gene expression in mice chronically treated with the SSRI paroxetine," Psychopharmacology, vol. 200, no. 4, pp. 557-572, 2008.

[37] Q. Wei, E. K. Hebda-Bauer, A. Pletsch et al., "Overexpressing the glucocorticoid receptor in forebrain causes an aging-like neuroendocrine phenotype and mild cognitive dysfunction," The Journal of Neuroscience, vol. 27, no. 33, pp. 8836-8844, 2007.

[38] M. L. Laudenslager, C. Noonan, C. Jacobsen et al., "Salivary cortisol among American Indians with and without posttraumatic stress disorder (PTSD): gender and alcohol influences," Brain, Behavior, and Immunity, vol. 23, no. 5, pp. 658-662, 2009.

[39] T. A. Mellman, D. D. Brown, E. S. Jenifer, M. M. S. Hipolito, and O. S. Randall, "Posttraumatic stress disorder and nocturnal blood pressure dipping in young adult african americans," Psychosomatic Medicine, vol. 71, no. 6, pp. 627-630, 2009.

[40] C. S. Ulmer, P. S. Calhoun, J. D. Edinger, H. R. Wagner, and J. C. Beckham, "Sleep disturbance and baroreceptor sensitivity in women with post-traumatic stress disorder," Journal of Traumatic Stress, vol. 22, no. 6, pp. 643-647, 2009.

[41] R. P. Allen, U. D. McCann, and G. A. Ricaurte, "Persistent effects of $( \pm)$ 3,4-methylenedioxymethamphetamine (MDMA, "ecstasy") on human sleep," Sleep, vol. 16, no. 6, pp. 560-564, 1993.

[42] H. Kerbage and S. Richa, "Non-antidepressant long-term treatment in post-traumatic stress disorder (PTSD)," Current Clinical Pharmacology. In press.

[43] P. Johansen and T. S. Krebs, "How could MDMA (ecstasy) help anxiety disorders? A neurobiological rationale," Journal of Psychopharmacology, vol. 23, no. 4, pp. 389-391, 2009.

[44] B. T. Callahan, B. J. Cord, and G. A. Ricaurte, "Long-term impairment of anterograde axonal transport along fiber projections originating in the rostral raphe nuclei after treatment with fenfluramine or methylenedioxymethamphetamine," Synapse, vol. 40, no. 2, pp. 113-121, 2001.

[45] C. Ádori, R. D. Andó, G. G. Kovács, and G. Bagdy, "Damage of serotonergic axons and immunolocalization of Hsp27, Hsp72, and Hsp90 molecular chaperones after a single dose of MDMA administration in dark agouti rat: temporal, spatial, and cellular 
patterns," Journal of Comparative Neurology, vol. 497, no. 2, pp. 251-269, 2006.

[46] I. Escobedo, I. Peraile, L. Orio, M. I. Colado, and E. O'Shea, "Evidence for a role of Hsp70 in the neuroprotection induced by heat shock pre-treatment against 3,4methylenedioxymethamphetamine toxicity in rat brain," Journal of Neurochemistry, vol. 101, no. 5, pp. 1272-1283, 2007.

[47] H. S. Sharma and S. F. Ali, "Acute administration of 3,4methylenedioxymethamphetamine induces profound hyperthermia, blood-brain barrier disruption, brain edema formation, and cell injury: an experimental study in rats and mice using biochemical and morphologic approaches," Annals of the New York Academy of Sciences, vol. 1139, pp. 242-258, 2008.

[48] N. Thiriet, B. Ladenheim, M. T. McCoy, and J. L. Cadet, "Analysis of ecstasy (MDMA)-induced transcriptional responses in the rat cortex," FASEB Journal, vol. 16, no. 14, pp. 1887-1894, 2002.

[49] M. Shankaran and G. A. Gudelsky, "Effect of 3,4-methylenedioxymethamphetamine (MDMA) on hippocampal dopamine and serotonin," Pharmacology Biochemistry and Behavior, vol. 61, no. 4, pp. 361-366, 1998. 

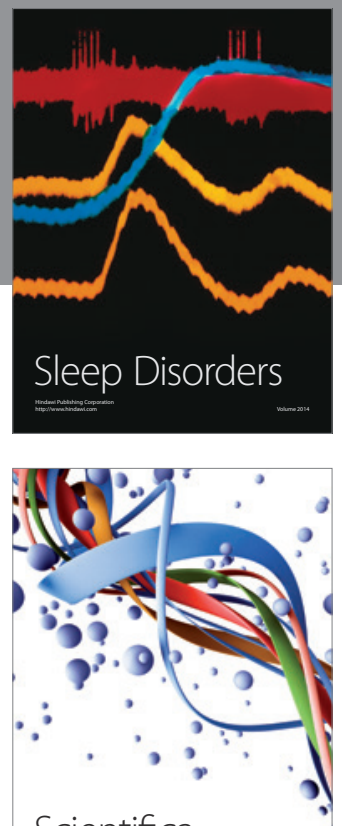

Scientifica
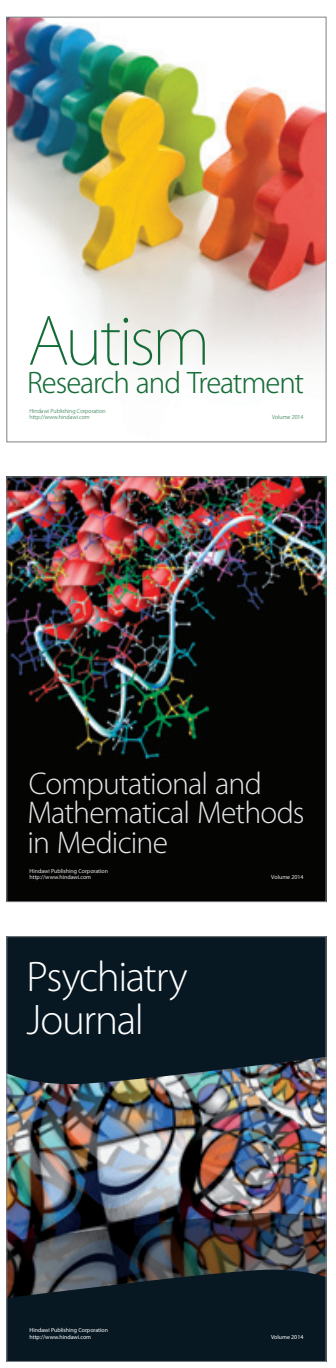
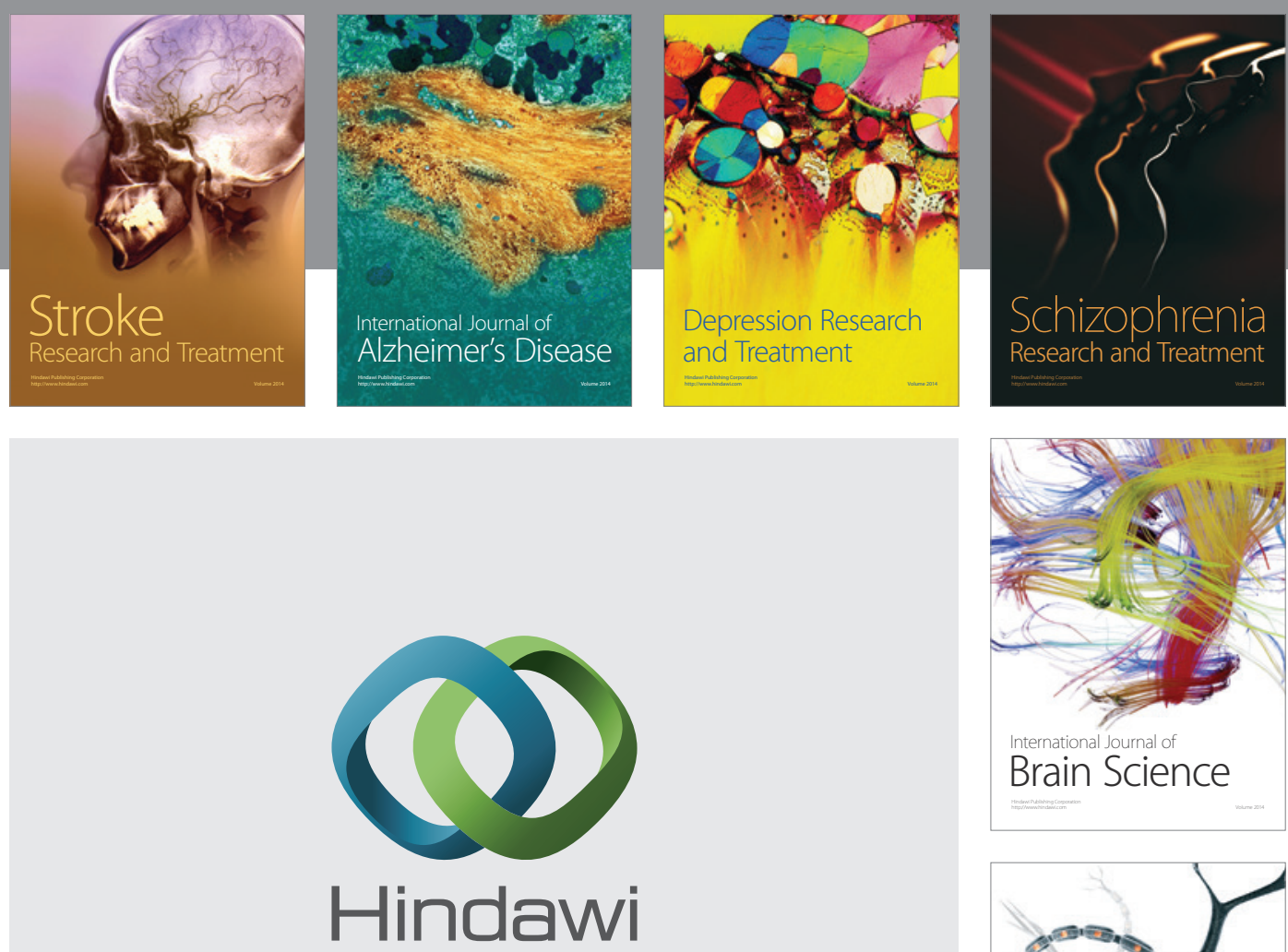

Submit your manuscripts at

http://www.hindawi.com
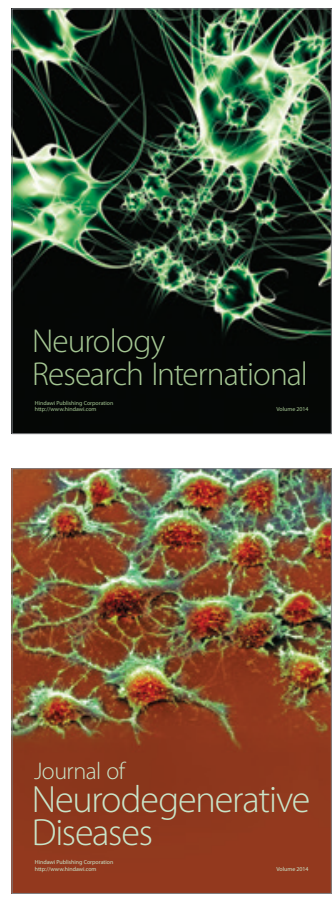

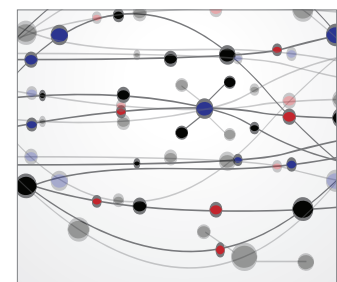

The Scientific World Journal
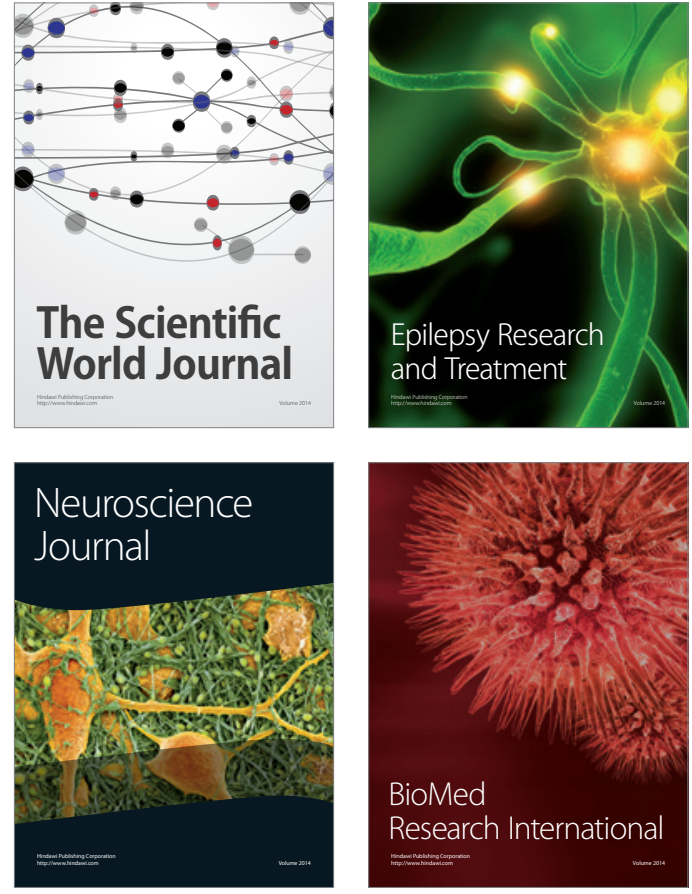

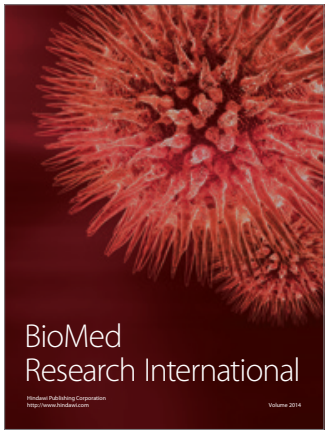

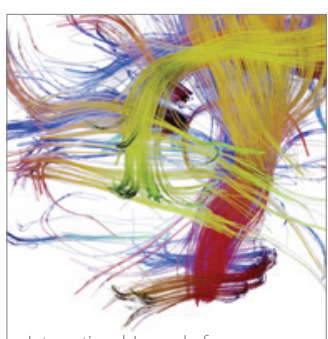

Brain Science

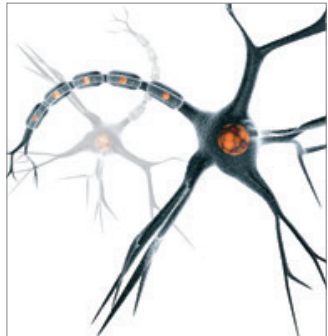

Neural Plasticity
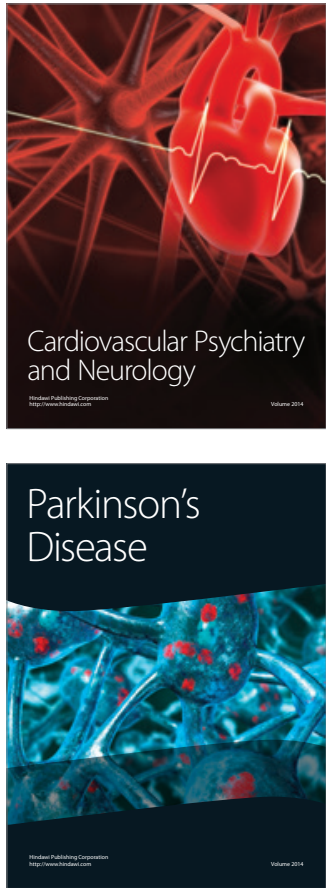